\title{
Simulation of a bioavtur production process from non-edible vegetable oil
}

\author{
Achmad Anggawirya Alimin ${ }^{1}$, and Bambang Heru Susanto ${ }^{1, *}$ \\ ${ }^{1}$ Chemical Engineering, Chemical Engineering Department, Faculty of Engineering,Universitas Indonesia, Indonesia.
}

\begin{abstract}
The increase in global aviation fuel demand has prompted ICAO to declare neutral carbon growth policy in 2050 by using bio based aviation fuel. The purpose of this study was to simulate the production of non-edible vegetable oil into bioavtur and obtain the most potential nonedible vegetable oil based on yield and conversion to be converted into bioavtur. Three potential sources to be converted into bioavtur are kosambi oil, nyamplung oil and kemiri sunan oil. This research was done by simulating of the hydroprocessing process with process simulator by varying the operating conditions on each raw material. Hydrotreating process was varied at 1-5 $\mathrm{MPa}$ pressure and temperature $250{ }^{\circ} \mathrm{C}-350^{\circ} \mathrm{C}$. The result showed the operating pressure with the highest conversion and yield are around $4 \mathrm{MPa}$. While the operating temperature with high conversion and yield are above $290^{\circ} \mathrm{C}$. Nyamplung oil has overall the largest yield and conversion than other nonedible vegetable oil with average $10 \%$ greater conversion and 3,3\% greater yield at $2 \mathrm{MPa}$.
\end{abstract}

\section{Introduction}

Commercialization of the aviation world has grown rapidly in the last 7 years, recorded in 2011 the number of domestic passenger flights of 59 million, this trend continues to grow until in 2015 the number of passengers increased to 75 million. Predicted this value will continue to grow in line with the equitable development of air transportation facilities in Indonesia. The increase in aviation also affects aviation fuel needs, by 2015 Indonesia needs 2.8 million kilo liters of avtur[1]. Bioavtur is widely used in conjunction with the campaign conducted by ICAO (International Commercial Airlines Association). Based on ICAO estimation, the aviation industry generates $2 \%$ of the total greenhouse gases in the atmosphere. In 2010, carbon dioxide accumulation in atmosphere reached 448 tons $(\mathrm{Mt})$ which predicted to accumulate nearly 682 to 755 Mt by 2020 , then 2700 Mt by 2050 if no action is taken. The increase in fuel demand and the potential increase in greenhouse gases prompted ICAO to declare neutral carbon growth by 2050 on aviation. In support of this policy the Indonesian government issues the Ministry of Energy and Mineral Resources's ministerial instruction number 12 of 2015 on bio-fuel mixing targets $5 \%$. Moreover, bioenergy preferably works as supporting strategies for energy in Java and Bali [2].

Indonesia is one of the largest palm oil producing countries in the world. The Association of Indonesian Palm Oil Companies (GAPKI) noted that Indonesia's palm oil production in 2016 reached 34.5 million tons [3]. However, palm oil (edible-vegetable oil) usage as

\footnotetext{
Corresponding author: bambanghs@che.ui.ac.id
}

fuel, usually contradicted with the usage as food source and without proper planning it will cause negative impact [4]. Therefore, some non-edible vegetable oils found in tropical country potential to be converted into biofuels. This plant has excellent productivity with a large conversion such as; Nyamplung $(22.2 \%$ free fatty acid content) [5], Kemiri Sunan (92.74\% H-Fame conversion) [6] and Kosambi (C18 acid content: $57.8 \%$ wt) [7].

Last study bioavturs showed that bioavtur can be obtained from vegetable oils through the Hydrotreating process in laboratory, from which the Bioavures can be mixed up to a mixing ratio of $50 \%$ with conversion of up to $96 \%$ of macauba oil [8]. While, Gutierrez-Antonio et.al achieve $82 \%$ biofuel conversion from castor oil by simulating hydroprocessing process [9]. While this paper will simulate hydroprocessing by using kemiri sunan oil, kesambi oil and nyamplung oil.to produce biofuel.

It is hoped that this research can provide a yield and conversion prediction from non-edible vegetable oil into bioavtur..

\section{Methodology}

A process simulation was performed to evaluate the overall yield and product conversion. As previously described, this study used raw materials with 3 type of non-edible vegetables oil with a production capacity of $300 \mathrm{~kg} /$ hour. Then optimized at the hydrotreating stage by varying the operating conditions to obtain optimal operating conditions. The entire scheme of the process can be seen in Fig. 1[10]. In hydrotreating process based on those figure, process divided into three stages. 


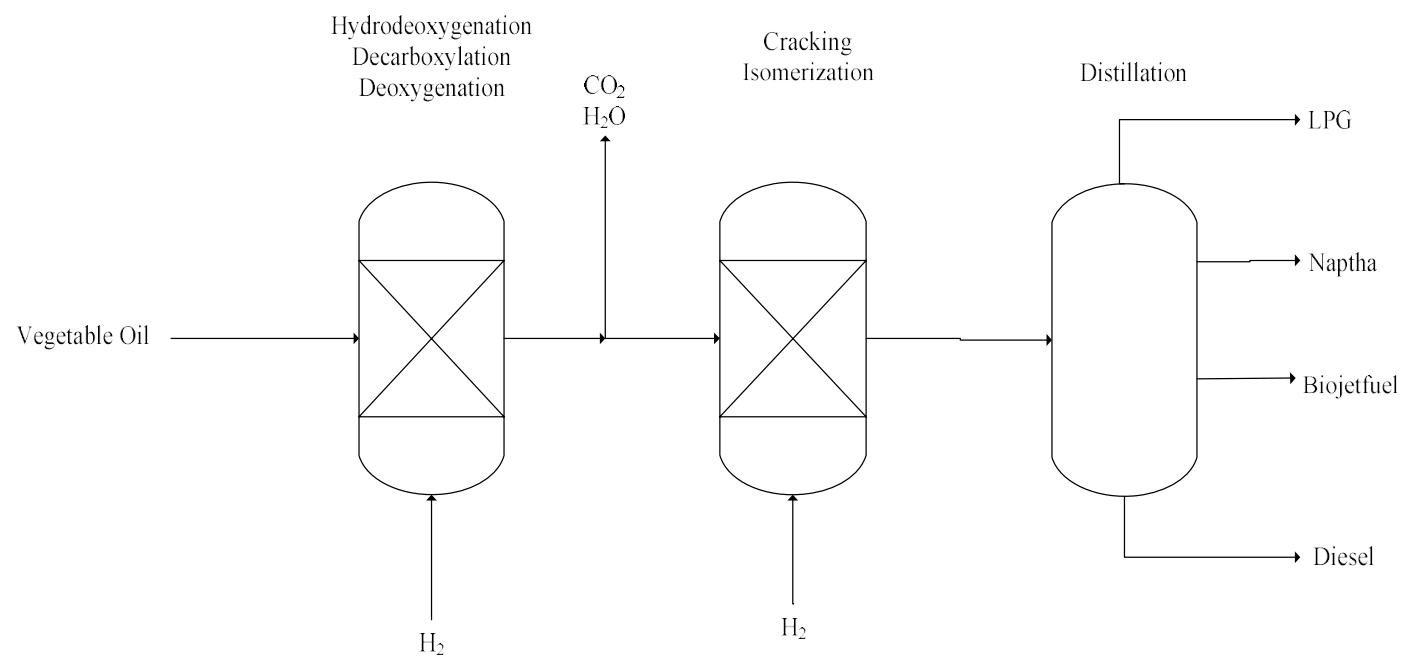

Fig. 1. Process Simulation Diagram [10]

First stage was hydrotreating to eliminate oxygen content in vegetable oil and produce long chain alkane. Second stage was hydrocracking which used to convert long alkane into shorter chain length. And the las stage was separation process, which used to divide product into bioLPG, biogasoline, bioavtur and renewable diesel.

\subsection{Materials}

The group of compounds undertaken in this study is divided into five, in the form of alkane compounds as the product, alkanol as intermediate, fatty acid as raw material, ester and additional compounds that are not sufficient to be grouped including water, hydrogen gas and carbon dioxide gas. Some of the compounds properties are not provided by simulation, so we use hypothetical compound to describe these compounds. All of the compound that we used are list based on reaction mechanism in hydrotreating mechanism in Kubickova[11]. Each of non-edible vegetable oil composistion in this simulation are listed in Table 1 based on their range of chain length and free fatty acid content. As seen in table 1, each of vegetable oil has different composition. Nyamplung oil has the largest FFA (free fatty acid) content, kemiri sunan has the largest $\mathrm{C} 18$ chain length content. Kesambi oil has the largest of $\mathrm{C} 20$ chain length. This composition difference will be evaluated due to yield and conversion that this vegetable oil reach.
Table 1. Non-Edible Vegetable Oil Composition

\begin{tabular}{|c|c|c|c|}
\hline $\begin{array}{c}\text { Fatty } \\
\text { Acid }\end{array}$ & $\begin{array}{c}\text { Nyamplung } \\
(\%)[12]\end{array}$ & $\begin{array}{c}\text { Kemiri } \\
\text { Sunan } \\
(\%)[13]\end{array}$ & $\begin{array}{c}\text { Kosambi } \\
(\%)[7]\end{array}$ \\
\hline C14 & 0.009 & 0 & 0.7 \\
\hline C16 & 14.26 & 10.1 & 8.7 \\
\hline C18 & 84.13 & 89.9 & 70.3 \\
\hline C20 & 1.66 & 0 & 20.2 \\
\hline C22 & 0.83 & 0 & 0 \\
\hline FFA & 20 & 2.6 & 5.01 \\
\hline
\end{tabular}

\subsection{Hydrotreating}

Hydroytreating process represents the formation of alkane carbon chains from fatty acids, by releasing oxygen groups in the form of carbon dioxide and water generally carried out in trickle bed reactors through the aid of $\mathrm{CoMo} / \mathrm{Al}_{2} \mathrm{O}_{3}$ catalysts and hydrogen. This process was carried out at varying temperatures and pressures. Variations are performed at pressures of $1 \mathrm{MPa}$ to $5 \mathrm{MPa}$ and temperatures of $250 \circ \mathrm{C}$ to $350^{\circ} \mathrm{C}$. The kinetic data incorporated in this process comprises kinetics including the decarboxylation and hydro-deoxigenation reactions taken from the results of laboratory experiments. 
The hydrotreating process of vegetable oil is carried out using kinetics data provided from by Kubickova and Kubicka[11] which conduct comprehensive research on rapeseed oil. The reaction mechanism can be seen in [11], which provide two mechanism paths. This mechanism including hydrodeoxygenation which produce water as side product with larger hydrogen demand and hydrodecarboxylation which produce carbon dioxide as side product with lower hydrogen demand. The assumption that all of the chain lenght variety has same reactivity is used, to apply kinetics in kinetic reaction.

\subsection{Hydrocracking}

The hydrocracking/Izomerization is the process of reforming the alkane hydrocarbon chain into shorter or aromatic hydrocarbon alkane chains by reacting the alkane with hydrogen in a fixed bed reactor. This process can be found in the oil refinery industry to produce light hydrocarbons such as gasoline, aviation and diesel from heavy distillates and residues.[14] found that at a pressure of 50-60 bar and a temperature of $240{ }^{\circ} \mathrm{C}$ the maximum conversion to isomers was $32 \%$, from $50 \%$ conversion to converted n-dodecane.

Gutierrez-Antonio et.al already use hydrocracking conversion data from steijns et.al to simulate biojet production by assuming normal alkanes with $\mathrm{C} 15$ to $\mathrm{C} 18$ atomic numbers having the same reactivity as ndodecane showed realistic results [9].

This simulation used the same hydrocracking assumption as Gutierrez-Antonio et.al which assuming normal alkanes with $\mathrm{C} 14$ to $\mathrm{C} 22$ having same reactivity as n-dodeacane with equal product distribution. Therefore, hydrocracking formed in conversion reactor with $50 \%$ conversion.

\subsection{Separation}

From the scheme of the above process flow diagram, it is known that the output of this system has large variety of alkane chain including propane to $\mathrm{C} 22$, unreacted raw material, intermediates and side product. Separation is carried out on the remaining hydrogen gas, intermediates and unreacted vegetable oil into recycle stream. While carbon dioxide gas and water into purge stream. Main product, large variety of alkane chain are divided into four types of product based on chain length which are bioLPG (propane and butane), biogasoline (C5-C9), bioavtur (C10$\mathrm{C} 15)$ and renewable diesel (C16-C22). This separation process held by component splitter to reduce the complexity of system.

\section{Result and Discussion}

After simulating bioavtur production process for each vegetable oil and operating condition, we will validate the result. Analysis held by comparing yield and conversion trend for variety operating condition. The conversion and yield result also analyzed by comparing the composition of each vegetable oil.

Result of this simulation was validated by comparing properties of bioavtur produced from simulation and jet fuel standard. Simulated bioavture has $752 \mathrm{~kg} / \mathrm{m}^{3}$ density which still density range with Jet B Wide-Cut Kerosene with $750-801 \mathrm{~kg} / \mathrm{m}^{3}$ density at $15^{\circ} \mathrm{C}$. Specific comparation between product and standard be seen in table 2 .

Table 2. Properties Comparation

\begin{tabular}{|c|c|c|}
\hline Standard & AvturStd & Bioavtur \\
\hline $\begin{array}{c}\text { Lower } \\
\text { Heating Value } \\
(\mathrm{MJ} / \mathrm{kg})\end{array}$ & $42.8(\mathrm{~min})$ & 44.46 \\
\hline $\begin{array}{c}\text { Density } \\
(\mathrm{kg} / \mathrm{m} 3) 15 \mathrm{C}\end{array}$ & $750-801$ & 756.1 \\
\hline $\begin{array}{c}\text { Boiling Point } \\
(\mathrm{C})\end{array}$ & $270(\max )$ & 244 \\
\hline $\begin{array}{c}\text { Viscosity } \\
\text { @20C (cP) }\end{array}$ & $\mathrm{n} / \mathrm{a}$ & 1.837 \\
\hline $\begin{array}{c}\text { Kinematic } \\
\text { Viscosity } \\
@ 20 \mathrm{C}(\mathrm{cSt})\end{array}$ & $8.8(\max )$ & 2.423 \\
\hline
\end{tabular}

\subsection{Yield and Conversion Result}

Yield and Conversion of each vegetable oil was reviewed from the overall process of the system by varying the hydrotreating process conditions. Each conversion and yield result then presented in graphical at Fig.2, where the axial shows the temperature in $\mathrm{C}^{\circ}$, the vertical axis showing yield and conversion in percent, and for each pressure variation has different mark in graph.

Each graph in Fig.2 shows the yield and conversion values for each temperature variation and the operating pressure applied to the kosambi, kemiri sunan and nyamplung oil. Based on the graph, yield and conversion values are directly proportional to operating temperatures with different slopes for each pressure, where the largest slope gained at $3 \mathrm{MPa}$ pressure. This trend also applied with pressure changes, increasing pressure cause increasing the value of yield and conversion from kemiri sunan, kosambi and nyamplung oil. The largest conversion increase only happened at $3 \mathrm{MPa}$ pressure comparing to other pressure. 
However, at the temperature variation with the smallest pressure $1 \mathrm{MPa}$, it shows a small increase in value of conversion from each vegetable oil from temperature range $250{ }^{\circ} \mathrm{C}$ to $290{ }^{\circ} \mathrm{C}$, a temperature increase after $290{ }^{\circ} \mathrm{C}$ has no major effect for conversion values and it is tended to be constant with temperature increases in the range of $290{ }^{\circ} \mathrm{C}$ to 340 ${ }^{\circ} \mathrm{C}$ and decrease at $350{ }^{\circ} \mathrm{C}$. At $2 \mathrm{MPa}$ pressure with temperature variation, yield and conversion consistently increase as temperature increases with small slopes. For all vegetable oil, yield and conversion big leap occurred at $3 \mathrm{MPa}$ pressure. Conversion increase nearly $20 \%$ at lowest temperature from pressure $2 \mathrm{MPa}$ to $3 \mathrm{MPa}$. While, yield increase around $6 \%$ at lowest temperature from pressure $2 \mathrm{MPa}$ to $3 \mathrm{MPa}$. This conversion increase occurs during temperature rise. Conversions above $90 \%$ for $3 \mathrm{MPa}$ pressure are achieved at $310{ }^{\circ} \mathrm{C}$ for most vegetable oil.

At $4 \mathrm{MPa}$ pressure, it tends to be more effective for lower temperatures (under $290^{\circ} \mathrm{C}$ ) because yield and conversion gap from lower pressure are much higher at that temperature range. While in the temperature range above $290^{\circ} \mathrm{C}$, although yield and conversion obtained is higher than $3 \mathrm{MPa}$ pressure but the increase is not significant. This conversion and yield trend happen for all the vegetable oil. At the $5 \mathrm{MPa}$ pressure evaluation, yield and conversion increments are not much different than the $4 \mathrm{MPa}$ pressure, although the conversion value is lower.

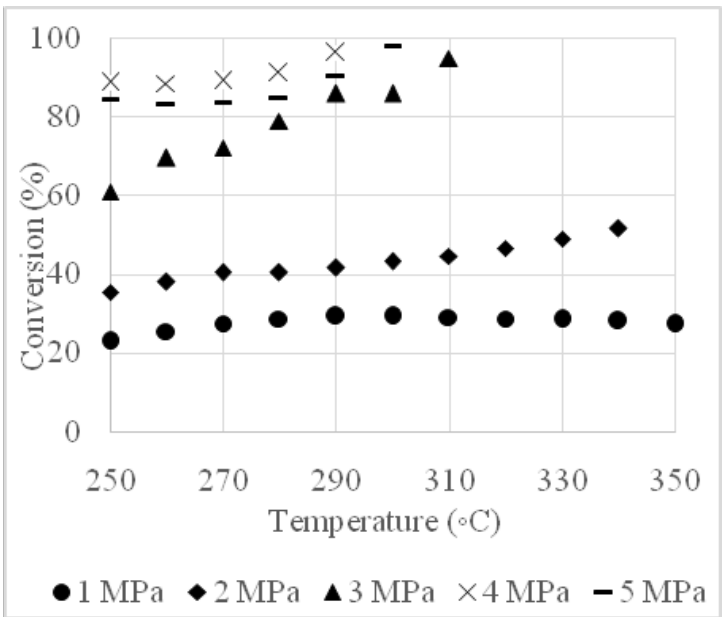

(a). Kosambi Oil Conversion

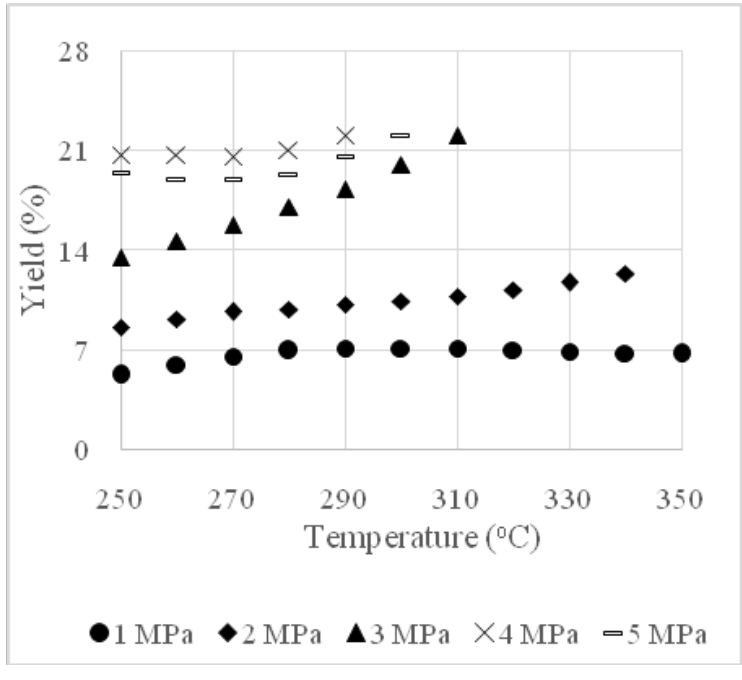

(b)Kosambi Oil Yield

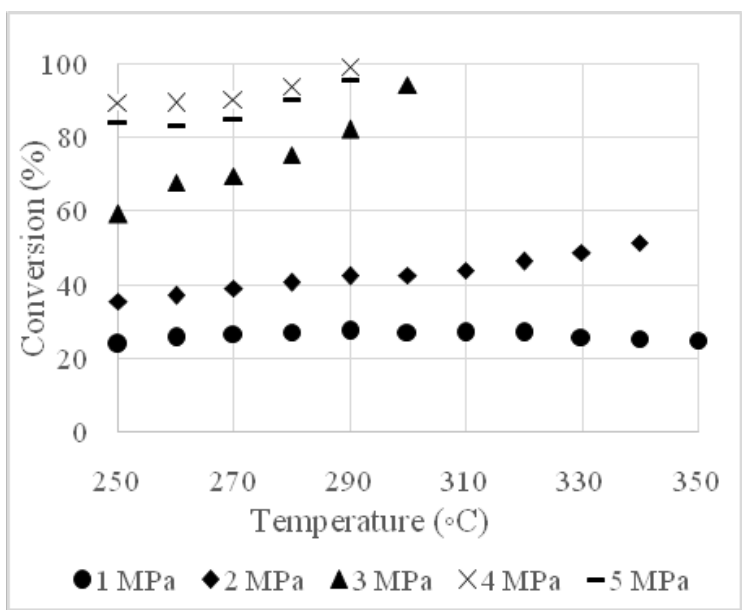

(c) Kemiri Sunan Oil Conversion

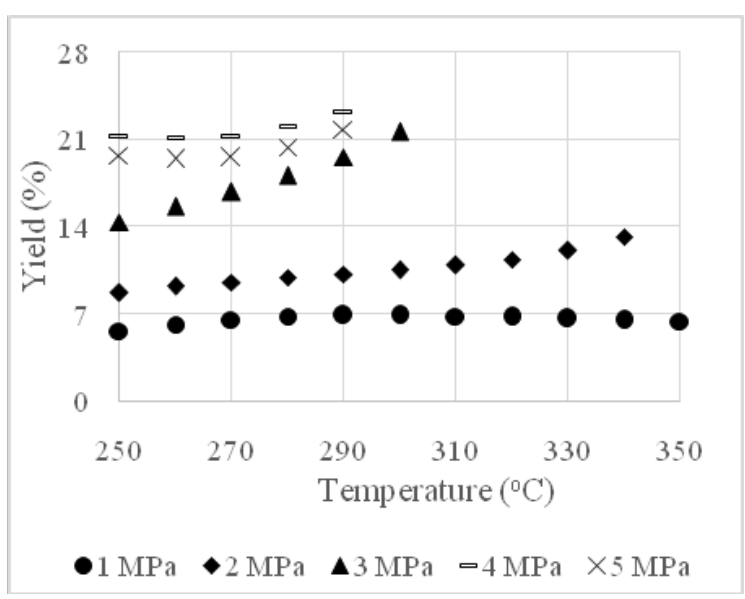

(d) Kemiri Sunan Oil Yield 


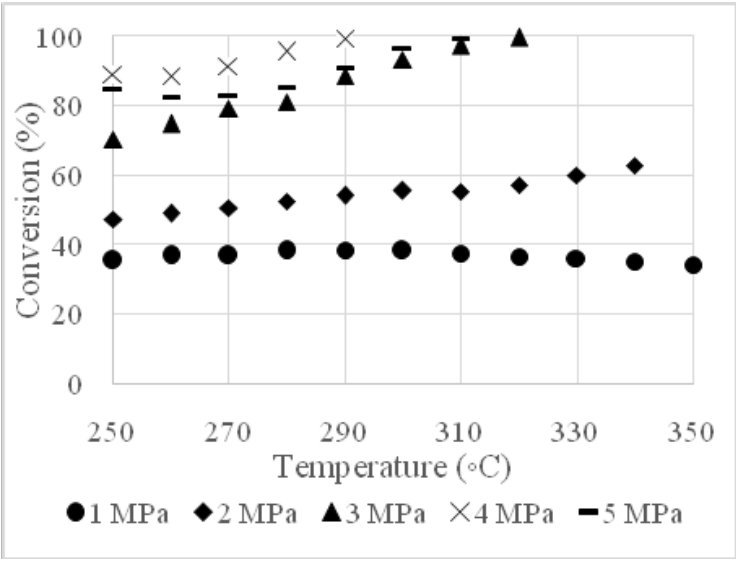

(e)Nyamplung Oil Conversion

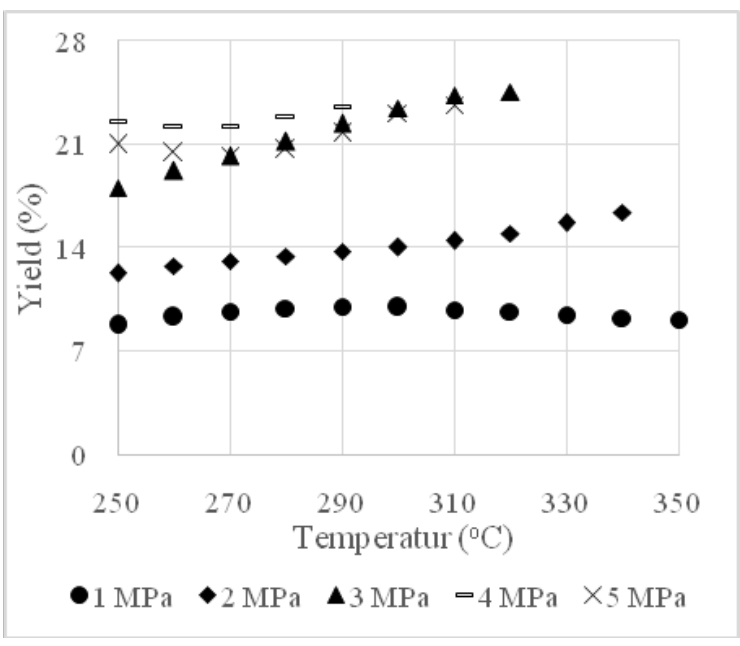

(f)Nyamplung Oil Yield

Fig.2. Variety of Yield and Conversion of Non-Edible Vegetable Oil

Overall for each vegetable oil, the conversion will tend to increase as the temperature rises at a pressure of 2 to $5 \mathrm{MPa}$. While for $1 \mathrm{MPa}$ pressure the conversion tends to be consistent or decrease after temperature $290{ }^{\circ} \mathrm{C}$. The most effective increase occurs at $3 \mathrm{MPa}$ pressure where the increase in conversion can rise up to $20 \%$. Then at $4 \mathrm{MPa}$ pressure, the conversion is more effective at temperatures below $290{ }^{\circ} \mathrm{C}$ because the conversion gap is still greater than the $3 \mathrm{MPa}$ pressure. For all vegetable oils conversion is decreased when evaluated at $5 \mathrm{MPa}$ pressure, although conversion difference is not too far compared to $4 \mathrm{MPa}$ pressure. Therefore, the operating pressure with the highest conversion and yield are around $4 \mathrm{MPa}$. While the operating temperature with high conversion and yield are above $290^{\circ} \mathrm{C}$.
All this happening trend for yield and conversion for each vegetable oil are purely because of reaction kinetics and composition which will be discussed in the next sub-chapter.

Based on the explanation above, the evaluation of the temperature is stopped at a certain higher temperature. Because at some point on those higher operating condition, mass balance from the system are negatives due to higher value of conversion (more than $100 \%$ ) forced purge stream into negatives value. However, purge installation in system was done to anticipate the flow rate of recycle stream. A very big recycle stream will make the system not feasible. At higher temperatures the conversion becomes larger while the raw material inrush is kept constant. This will result in the system forcing the stream purge to be negative value makes the simulation result impossible. Therefore, variation of temperature at some point are not evaluate in this simulation.

\subsection{Vegetable Oil Composition Effect}

In this study, three types of vegetable oils are used; kesambi oil, kemiri sunan oil and nyaplung oil. Each composition of the vegetable oil is different so that the effect of the oil composition will be evaluated. Composition of each vegetable oil was showed in Table 1. The evaluation is performed on the oil composition of the conversion and yield. It is important to analyze vegetable oil composition effect. Because vegetable oil composition linked into reaction mechanism that simulate in this research.

The graph in Fig.3 (a) shows the bioavur yield of vegetable oil at a pressure of $2 \mathrm{MPa}$ with a temperature variation. $2 \mathrm{MPa}$ pressure is taken as a reference because at this pressure the complete yield data evaluated from various temperatures of $250{ }^{\circ} \mathrm{C}$ to $350 \circ \mathrm{C}$ and the yield gradient in each vegetable oil are greater than at $1 \mathrm{MPa}$. From the graph above seen as the rising temperatures tend to increase vegetable oil yields for all vegetable oils, this is supported by the increase of conversion from vegetable oil itself. The highest yield of was achieved from Nyamplung Oil with a value of $12,5 \%$ at the lowest temperature $250 \circ \mathrm{C}$ followed by kemiri sunan and kesambi oil.

When viewed from the composition of vegetable oil, FFA content is quite influential on the value of the yield but limited only to affect the conversion. This showed by the largest conversion of nyamplung oil than other vegetable oil which has the largest FFA content around $20 \%$, while other vegetable oil like kesambi and kemiri sunan only have $5.01 \%$ and $2.5 \%$ FFA. 


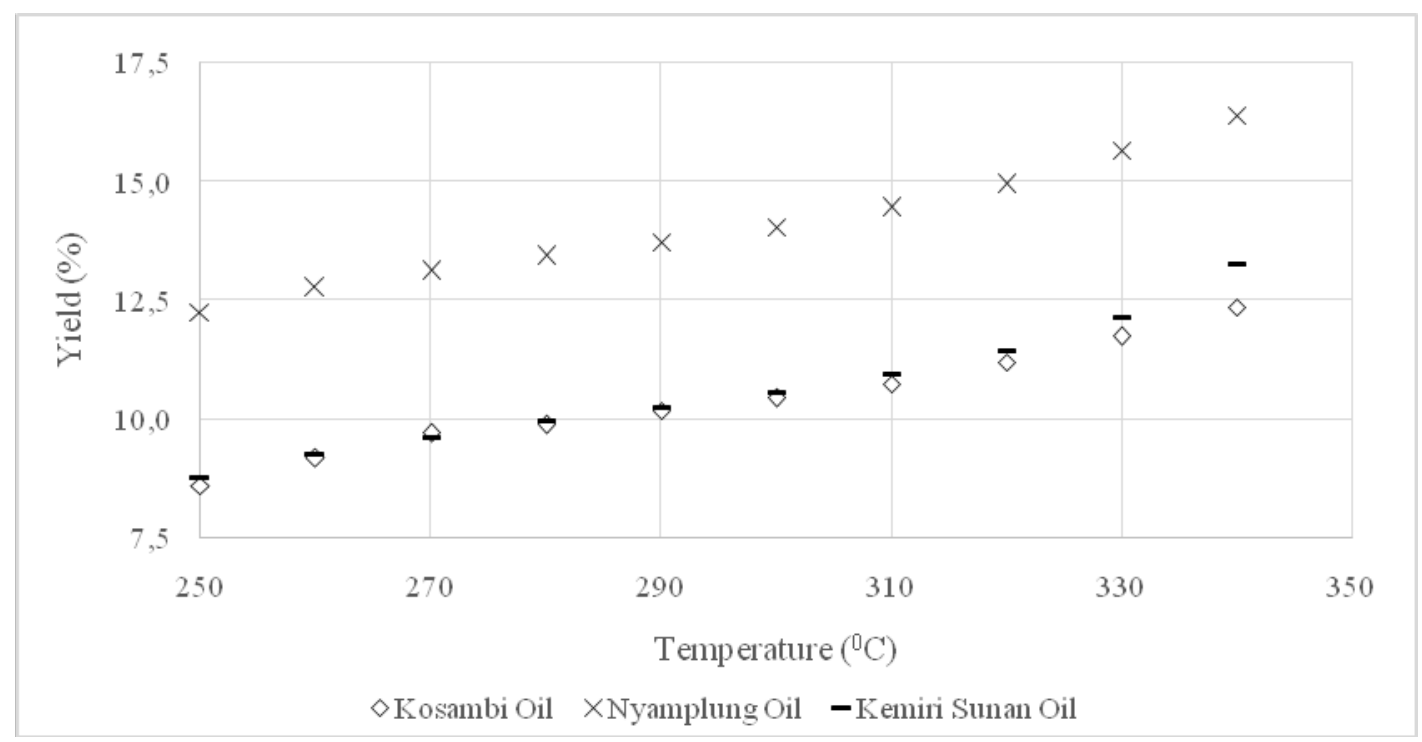

(a) Vegetable oil yield at 2MPa with temperature variation

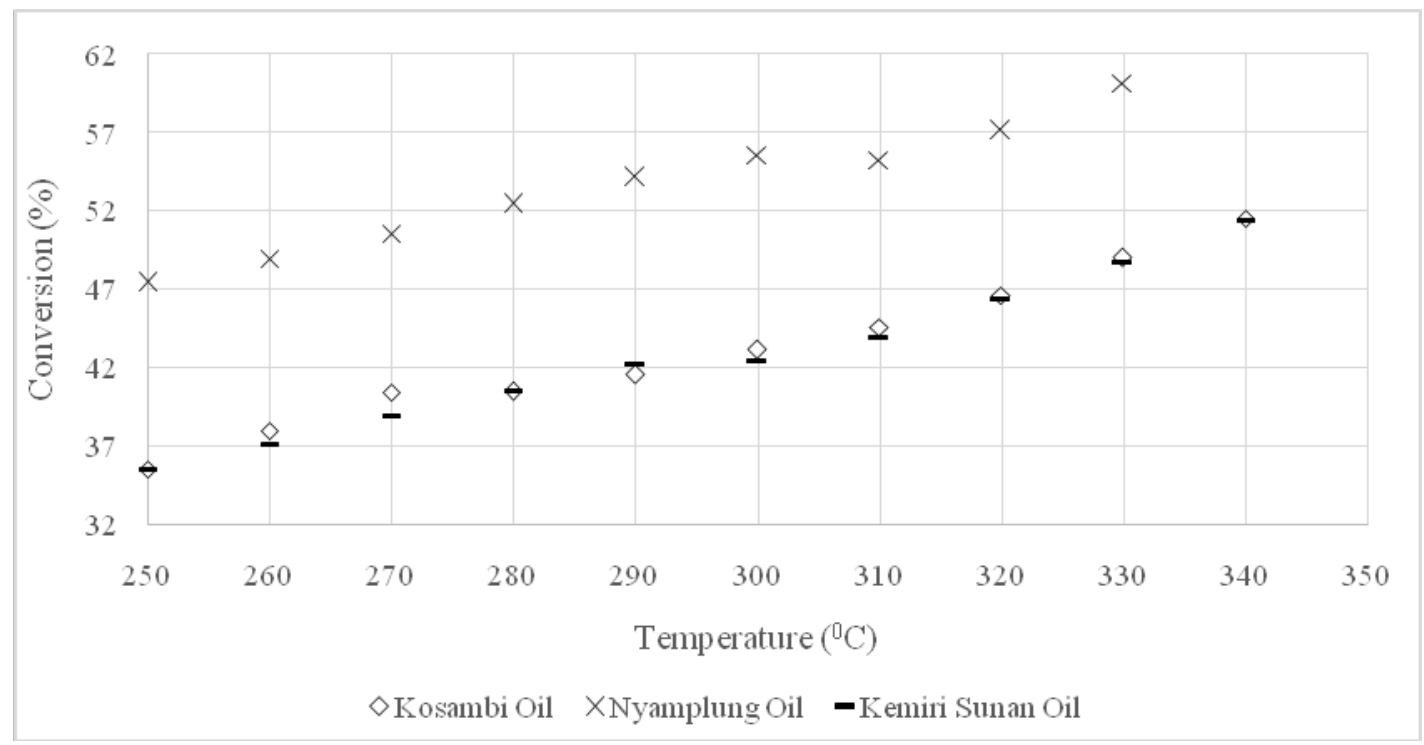

(b) Vegetable oil conversion at $2 \mathrm{MPa}$ with temperature variation

Fig.3.Variation of Vegetable Oil Yield and Conversion

To evaluate effect on bioavtur yields due to the composition of fatty acid chain length of each vegetable oil. we minimize the impact of conversion due to FFA, we will review vegetable oils with the lowest FFA levels which is kemiri sunan oil (2.6\% FFA) and kesambi oil $(5.01 \%)$. In Fig. 3 (b) it showed that both of kosambi oil and kemiri sunan oil has the slightly the same number of conversion. However, if we evaluate Fig.3 (a) kemiri sunan tend to have better yield than kesambi oil. By comparing the fatty acid composition, kemiri sunan tend to have lower chain length of fatty acid while kesambi oil has longer fatty acid including $20 \%$ of arachidic acid (C20). As the temperature increase, yield gap between kemiri sunan and kosambi oil are larger with leap on kemiri sunan. This result showed that, vegetable oils that have shorter chain lengths will have greater bioavur yields more over with the increase of temperature.

\section{Conclusion}

In this study, bioavure production is simulated through hydroprocessing of non-edible vegetable oil with variation in Hydrotreating process to evaluated yield, conversion. The result showed Nyamplung oil has overall the largest yield and conversion due to largest FFA content. While, the operating pressure with the highest conversion and yield are around $4 \mathrm{MPa}$. While 
the operating temperature with high conversion and yield are above $290 \circ \mathrm{C}$.

Director of Research and Community Service (DRPM UI) through International Indexed Publication Grant for Researcher (PITTA) Universitas Indonesia 2018 with contract No.2389/UN2.R3.1/HKP.05.00/2018 is acknowledged for the financial support to carry out the present study.

\section{References}

1. Badan Pusat Statistik Indonesia Report, Statistik Transportasi Udara, BPS-Indonesia, Jakarta, (2016).

2. M. Gunter. International Journal of Technology. 9(2). 257-266. (2018).

3. GAPKI Report, Gabungan Pengusaha Kelapa Sawit Indonesia, Jakarta, (2016)

4. M. M. Gui, K. T. Lee, S. Bhatia. Energy 133, 1646-1653 (2008)

5. M. K. Charudatta, A. Ramanathan. Int $J$ of Green Energy (2017)

6. E. Ramayeni, B. H. Susanto and D. F. Prakatama, IOP Conf. Ser.: Earth Environ. Sci. 105, 012055 (2017)

7. C. Palanuvej, N. Vipunngun. J. Health Res.4,22 (2008)

8. V. P. Sousa, C. C. Cardoso, V. M. D. Pasa, Fuel Processing Technolgy143, 35-42 (2016)

9. C. Gutierrez-Antonio, G. Castro, D. L. Flores, S. A. Hernandes, Renewable and Sustainable Energy Reviews, 709-729 (2017).

10. L. Tao, W. Wang, Renewable and Sustainable Energy Reviews 53, 801-822 (2016)

11. D. Kubickova, V. Tukac, Advances in Chemical Engineering 42, 141-193 (2010).

12. M. Tjukup, S. Endang. Jurnal Natur Indonesia. 13, 112-117 (2011)

13. D. F. Pratama, B. H. Susanto and E. Ramayeni, IOP Conf. Ser: Earth Environ. Sci. 105, 012056 (2017).

14. M. Steijns, G. Froment, P. Jacobs, J. Utterhaeven, J. Weitkamp, Ind. Eng. Chem. Prod. Res. Dev. 20. 654-660 (1981) 